\title{
Language documentation and revitalization among the Siona of the Putumayo, Colombia: the potential of digitization for the social life of ethnographic material
}

Documentación y revitalización del lenguaje entre los Siona del Putumayo, Colombia: el potencial de la digitalización para la vida social del material etnográfico

Documentation et revitalisation de la langue chez les Siona du Putumayo, Colombie : le potentiel de la numérisation pour la vie sociale du matériel ethnographique

\section{Esther Jean Langdon}

\section{OpenEdition Journals}

\section{Electronic version}

URL: https://journals.openedition.org/jsa/18933

DOI: 10.4000/jsa.18933

ISSN: 1957-7842

Publisher

Société des américanistes

\section{Printed version}

Date of publication: 15 December 2020

Number of pages: 129-150

ISSN: 0037-9174

Electronic reference

Esther Jean Langdon, "Language documentation and revitalization among the Siona of the Putumayo, Colombia: the potential of digitization for the social life of ethnographic material", Journal de la Société des américanistes [Online], 106-2 | 2020, Online since 30 December 2020, connection on 16 September 2022. URL: http://journals.openedition.org/jsa/18933 ; DOI: https://doi.org/10.4000/jsa.18933 


\title{
Language documentation and revitalization among the Siona of the Putumayo, Colombia: the potential of digitization for the social life of ethnographic material
}

\author{
Esther Jean LANGDON *
}

This paper discusses an ongoing project of documentation and language revitalization among the Siona of the Putumayo, Colombia, and evaluates the potential of the return of audio recordings from the 1970s in digital format. Recognition of the potential of this material has been mixed and raises complex questions about the limits and benefits of modern technology to preserve the social life of oral literature. Local social and political organization and the politics of cultural survival determine how the material is perceived and possibilities of collaboration. Finally, the paper examines the differences between indigenous expectations of audio recordings and those of the anthropologist, indicating that digitization fixes, decontextualizes and recontextualizes oral literature within the current political context in which indigenous peoples seek to identify cultural patrimony in defense of their rights. [Key words: oral literature, digitization, patrimony, Siona Indians, cultural revitalization.]

Documentación y revitalización del lenguaje entre los Siona del Putumayo, Colombia: el potencial de la digitalización para la vida social del material etnográfico. Este artículo discute un proyecto en curso de documentación y revitalización del lenguaje entre los Siona del Putumayo, Colombia, y evalúa el potencial de la recuperación de registros de audio de los años 1970' por medio de su digitalización. El reconocimiento de las posibilidades de este material ha sido dispar y levanta preguntas complejas sobre os límites y beneficios de las nuevas tecnologías para la preservación de la vida social de la literatura oral. La organización local, social y política, así como las políticas de preservación cultural determinan cómo el material es percibido y las posibilidades de colaboración. Finalmente, este artículo examina las diferencias entre las expectativas de los indígenas y las del antropólogo sobre las grabaciones de audio, indicando que la digitalización fija, descontextualiza y recontextualiza la literatura oral al interior del contexto político en el cual los pueblos indígenas buscan identificar su patrimonio cultural en defensa de sus derechos. [Palabras clave: literatura oral, digitalización, patrimonio, pueblo Siona, revitalización cultural.]

* Pós-Graduação em Antropologia Social, Universidade Federal de Santa Catarina, Florianópolis, Brasil [estherjeanbr@gmail.com]. 
Documentation et revitalisation de la langue chez les Siona du Putumayo, Colombie: le potentiel de la numérisation pour la vie sociale du matériel ethnographique. Cet article analyse un projet de documentation et de revitalisation de la langue actuellement en cours chez les Siona du Putumayo (Colombie). Il s'intéresse notamment à l'impact de la restitution sous forme numérique d'enregistrements audio des années 1970. En dépit des nombreuses possibilités offertes par ce matériel, cette restitution a reçu un accueil mitigé, soulevant des questions complexes sur les limites et les avantages des nouvelles technologies pour la préservation de la vie sociale de la littérature orale. L'organisation locale, sociale et politique, ainsi que les politiques de préservation de la culture déterminent la manière dont ces matériaux sont perçus et les possibilités de collaboration. Enfin, cet article examine les différences entre les attentes des peuples autochtones et celles de l'anthropologue en ce qui concerne les enregistrements audio, indiquant que la numérisation fige, décontextualise et recontextualise la littérature orale dans le cadre politique au sein duquel les peuples autochtones cherchent à identifier leur patrimoine culturel comme défense de leurs droits. [Mots-clés : littérature orale, numérisation, patrimoine, Siona, revitalisation culturelle.]

This paper discusses an ongoing project of documentation and language revitalization among the Siona, a Western Tucanoan group living on the Putumayo River, which divides Colombia and Ecuador in Northwest Amazonia. It evaluates the potential of the return of ethnographic material recorded 50 years ago in digital format. I conducted fieldwork in Buenavista, the largest Siona community, from 1970 to 1973, and continued to return until 1992, when the region became the center of armed violence. During the years I was unable to visit the region, I received several grants to continue my documentation and translation work. I resumed trips to Colombia in 2012, offering collaboration with the Siona through the return of ethnographic material. ${ }^{1}$ Although photos and shamanic art are part of the material made accessible through digitization, this paper analyzes the return of oral literature and the implications of context for its reception. Three narrative collections are involved: (1) audiotapes of narratives told by elders in the native language I recorded between 1970 and 1973 (2) handwritten narratives in Siona transcribed by Luis Felinto Yaiguaje in

1. Research on translation of Siona texts and partial funding for fieldwork has been supported in Brazil by Scientific Productivity Grants (Bolsa de Produtividade) from CNPq (National Council of Scientific and Technological Development/Ministry of Science and Technology) since 1988. Research on translation and documentation was also conducted at Indiana University with Richard Bauman (1993-1994) with a grant from CAPES (Coordinating Agency for Professional Training in Higher Education/Ministry of Education) and at the University of Massachusetts with the Translations Studies Center and Department of Anthropology (2008, 2012-2013) with grants from both CAPES and CNPq. Since 2012, The National Institute for Science and Technology: Brazil Plural (INCT Brasil Plural) has partially funded the trips to Siona communities and the workshops conducted in Mocoa and Buenavista. 
the 1960s; and (3) recently discovered manuscripts of the linguist Manuel José Casas Manrique (1892-1973), who worked with Siona speakers from the 1930s to 1960s. The greatest part of his manuscripts consists of narratives told by Luis Felinto Yaiguaje when he served as linguistic informant in Bogotá in the 1960s. Digitized materials resulting from my research have been returned to three Siona communities during different periods over the past eight years, and their mixed reception raises important questions about the limits and benefits of modern technology to preserve the social life of ethnographic material.

The narratives are an important documentation of the Siona perception of the ideal life and the impact of the presence of outsiders. Through them it is possible to chart the movements of the semi-nomadic communities that migrated because of epidemics or the deaths of shamanic leaders (Langdon 1991; Mongua Calderón and Langdon 2020) and resistance to European invasion of their territory (Langdon 2018). The narratives yield important information about shamanic activities, territorial occupation, migrations, social organization and intercommunity conflicts. Oral literature has an important potential not only for the revitalization of language but also for the decolonization of indigenous history and the affirmation of territorial rights (Hershey, McCormack and Newell 2014). As an anthropologist, I was initially concerned with the translation, analysis and preservation of Siona material, seeking archival collections and museums adequate for deposit. However, focus on the return of this material and attempts to collaboratively engage the Siona according to their motivations and understandings have become the primary objectives of my research since 2012.

The work is ongoing, with no ready answers or techniques, and thus I examine the return of material among the Siona as an extended case study in order to highlight several issues and difficulties encountered during this process. In spite of the obvious value of narrative documentation and digitization as a potential source for ethnoeducation and cultural revitalization, the perception, reception and appropriation of digital material depends not only on the format in which it is available, but also on timing, local contexts and ongoing social political relations. Narrations (or performance) of oral texts that are recorded or transcribed represent dynamic social practices. They are taken from their original context, transformed into fixed forms, whether in print or digital formats, and recontextualized. They are given a new social life and inserted into new situations characterized by different expectations as well as new social and political functions (Briggs and Bauman 1992).

In the following pages, I describe the different social contexts and formats of the narrative collections recorded in the Siona language by myself, Felinto Piaguaje and the linguist Casas Manrique. Although they are highly relevant to ongoing linguistic and cultural revitalization goals outlined by the Siona (Portela Guarín et al. 2003), the potential of this material for the contemporary 
context has yet to be fully realized or developed. Efforts to familiarize the Siona with these texts have been made through workshops with bilingual speakers and indigenous teachers; negotiations in community assemblies following yajé rituals; and individual encounters with elders and political leaders. The material has been returned in printed form with translation and digital audio reproduction without translation. As will be seen, historical factors and the socio-political contexts of the return of the material have determined the heterogeneity of responses at different moments and among different groups, affecting the understanding of the potential of the material as well as interest and receptivity.

\section{History and the sources of the texts}

Three major extractive periods mark the history told in the narratives: fluvial gold mining in the 17th century; the quinine and rubber boom from 1870 to 1930; petroleum and coca production beginning in the 1950s and lasting to the present. The traditional territory of Western Tucanoan speakers spanned the regions between the Caquetá, Putumayo, Aguarico and Napo Rivers in Colombia, Ecuador and Peru. The native population, with a conservative estimate of 8,000 at the time of the Conquest (Langdon 2014, p. 48), was significantly reduced due to epidemics and armed conflict that began in the 17 th century with fluvial gold mining and the Franciscans' efforts to civilize the native populations and harness their labor. Gold extraction was followed by that of quinine and rubber, bringing new waves of epidemics and intense population mobility (Wasserstrom 2014). The Capuchin padres also entered the territory during this extractive period, relocating communities and attempting to civilize and Christianize the survivors of the Franciscan missions. By the 1930s, the Western Tucanoan population on the Putumayo River was reduced to some 300 people. Petroleum exploration brought new employment opportunities and the completion of a road from the highlands to the Putumayo River in the 1960s. Mestizos flooded down from the highlands, invading the territories of the indigenous populations and surrounding their settlements. By the mid-1960s, there were no practicing curacas (shamans), and the last shaman chief (cacique curaca) of Buenavista died in 1962. When I arrived in 1970, the weekly collective yajé (Banisteriopsis sp., ayahuasca) rituals, language, traditional dress and material culture were being abandoned, as the Siona established diverse social and economic relations with their non-indigenous neighbors. About half of the Western Tucanoans on the Putumayo lived in Buenavista, the only indigenous reserve (resguardo) with protective status on the river. The rest of the Western Tucanoans were scattered along its banks in smaller groups living among the growing colonist population. Then, as today, the majority of the Western Tucanoan descendants on the Putumayo identified as Siona or Zio Bain. 


\section{Siona narratives on audiotape}

My doctoral research centered on the shaman's role in serious misfortune and the translation of complex concepts and notions of shamanic cosmology (Langdon 2014). At the time, Spanish was becoming the predominant language in public contexts and the youth did not speak Siona. I quickly learned that their principal concepts expressing a multidimensional universe (Langdon 2013) were not translatable into Spanish and, thus, I began to learn the language through recording narratives in Siona. During three years, I recorded, transcribed and translated over 130 narratives told by five elders. My equipment consisted of a battery-powered Uher reel-to-reel tape-recorder and a lightweight Olivetti portable typewriter. The narratives proved to be an extremely rich source of poetic creativity and knowledge about the shamanic world. After each recording session, I transcribed the narratives and then worked with the narrator, revising the transcription to aid in my translation. This methodology led to a true dialogue about Siona ontology. As the narrators came to understand my interests, they initiated and guided the sequence of narrations that became the basis of our discussions. The oral texts are not only mythical and historical narratives, but also personal experiences of shamanic apprenticeship, journeys to invisible realms of the universe, dreams and illnesses caused by sorcery.

\section{Luis Felinto Piaguaje's texts}

The entire community knew of my documentation work, ${ }^{2}$ although few seemed to take interest. In 1971, Luis Felinto Piaguaje, an indigenous intellectual in his mid-20s, shared narratives he had collected from elders in the 1960s. After spending a number of years in Bogotá working with Manuel José Casas Manrique, who taught him to write his language, he collected some 45 narratives from the elders upon his return to Buenavista, using a non-standard orthography created by the linguist. When he dictated his handwritten manuscripts to me, I typed them on my Olivetti using the orthography developed by the linguist Alvaro Wheeler (1970). These narratives center less on shamanic battles and experiences, but are an important repository of information about Siona history, daily life and social organization. The narrators told of life in their villages during the first half of the 20th century before the influx of colonists, and the narratives represent an important source of cultural heritage.

\section{Casas Manrique's manuscripts}

During trips to Buenavista from 1980 to 1992, I met with Felinto and discussed the importance of publishing his collection of narratives. Felinto always

2. I was the first school teacher in Buenavista at their request and then later served as the local photographer. 
asked what had happened to the work that Casas Manrique had produced with him during his years in Bogotá. Several times when in the Colombian capital, I inquired about the manuscripts and was always informed that they had been destroyed or lost. However, in 2012, I discovered that Professor Karl Langebaek of the Universidad de los Andes had possession of manuscripts found by Casa Manrique's grandson. I was finally able to examine them in 2017. The manuscripts consist of some 950-1,000 handwritten pages, grouped in five manila folders, and include notes from the 1940s to the 1960s made during field trips and his work with indigenous youth in Bogotá. Over half of the five folders contain Siona narratives and word lists, and much of this is the product of Felinto's collaboration. The ethnohistorian Camilo Mongua Calderón (2018), a specialist in archival work, took digital photos of the original manuscripts and transformed them into PDF files. Examination of the narratives indicates that many are versions similar to those that Felinto recorded after his return to Buenavista. These manuscripts, like Felinto's texts, represent Siona collective memory in narrative form.

The manuscripts are in a very poor state of preservation and legible copies cannot be printed from the photos. A more sophisticated technology of reproduction is necessary. These manuscripts need to be deposited in a place with adequate environmental conditions to prevent continual deterioration, but the issue of who should have "guardianship" (Kowall 2013) over them needs to be addressed.

\section{Migration and ethnic revitalization}

The economic, environmental and social context of the Siona has changed radically over the last five decades, as they have struggled to survive, physically and ethnically, in a region permeated by armed violence (ACNUR 2006). They have been involved in a complex field of negotiations with the State, non-governmental organizations, extractive industries and diverse armed groups (paramilitaries, drug traffickers, military and guerrillas). Cultural revitalization projects have been key in negotiations with the State and NGOs, not only for guaranteeing the rights and autonomy of the Siona as an indigenous people in Colombia, but also for economic reasons. In 2009, the group was identified as linguistically and culturally at risk (Corte Constitucional 2009).

Although cocaine and guerrilla activities began in the late 1970s in the region, the 1990s brought increased cocaine production and a new wave of migrants. New actors arrived to dispute control of the region, among them Fuerzas Armadas Revolucionarias de Colombia (FARC), paramilitaries and drug lords from Medellín and Cali. FARC controlled much of the region in the 1990s and strove to hinder expansion of petroleum extraction. Buenavista was caught in 
the crossfire, as the reserve was invaded by armed forces on all sides. FARC recruited Siona youth, sometimes forcibly; the community was stigmatized and associated with the revolutionary forces. All the families have had members assassinated by one armed group or another. In addition, the territory has suffered irreparable environmental degradation due to bombings of glyphosate ${ }^{3}$ and petroleum extraction. Guerrillas planted landmines throughout the reserve, restricting the circulation of residents as well as hunting and fishing activities.

In the face of this violence, Siona families began migrating in the late 1990s to the urban areas of Puerto Asís and Mocoa, living in conditions of poverty and without adequate sanitation or health services (ACNUR 2006). The peace agreement between FARC and the Colombian government in 2015 brought the residents of Buenavista a sense of relief from the fear and violence that had plagued the community, and some families that had fled began to return. However, in July 2019, the military reinstated its invasive presence in the community in response to the return of FARC dissidents who renewed their attempts to control residents' movements. ${ }^{4}$

In spite of the violence, the Siona have increasingly organized themselves to defend their cultural identity and territory. Their survival as an indigenous people has been supported by the Colombian Constitution of 1991, which recognizes the multi-ethnic and multicultural character of the State and grants indigenous peoples increased rights and autonomy. The Constitution grants collective ownership of indigenous territories, called resguardos, with the right to prior informed consent for development projects proposed for their lands. In addition, the Constitution recognizes the cabildo (council) as the form of indigenous governance, composed of the elected officials of governador, alcalde mayor, aguaciles, treasurer, and fiscal. Today there are six Siona resguardos and

3. In 1994, aerial fumigation of coca plantations with the toxic herbicide glyphosate began and increased significantly during the next 10 years. As part of Plan Colombia implemented in 1999, it was defined as a policy for social development, deactivation of violence and the construction of peace. However, it became a counterinsurgency strategy central to efforts to drive out the guerrillas and take control of the region so that petroleum extraction could progress.

4. Comisión de Derechos Humanos de los Pueblos Indígenas, "Solicitud de acción urgente" por las violaciones sistemáticas al pueblo indígena Siona especificamente del resguardo de Buenavista, departamento del Putumao [online], August 17, 2019, https://comisionddhhpi. com/2019/08/17/solicitud-de-accion-urgente-por-las-violaciones-sistematicas-al-puebloindigena-siona-especificamente-del-resguardo-de-buenavista-departamento-del-putumayo/, accessed 01/12/2020; Organización Nacional de los Pueblos Indígenas de la Amazonía Colombiana, "Persisten amenazas y hostigamiento contra la población del resguardo ZioBain (Siona) de Buenavista" [online], July 22, 2017, https://opiac.org.co/persistenamenazas-y-hostigamiento-contra-la-poblacion-del-resguardo-ziobain-siona-de-buenavista/, accessed 01/12/20. 


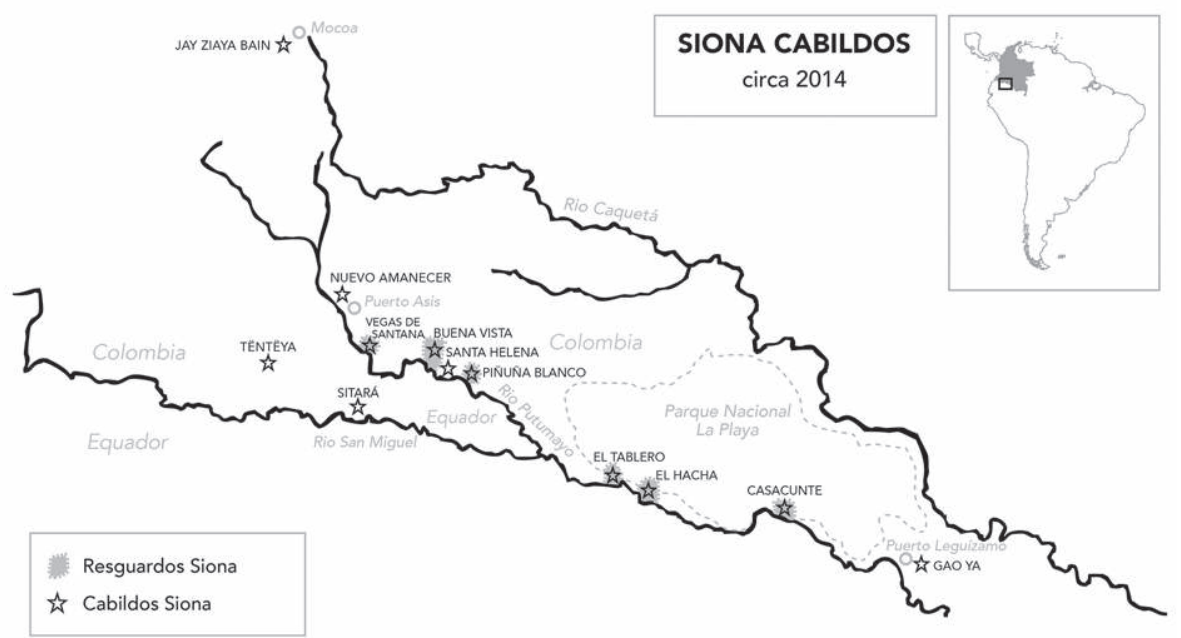

Fig. 1 - Location of Siona Cabildos

(adapted from Musalem Nazar 2016, p. 47)

12 cabildos, two of which are located in the cities of Puerto Asís and Mocoa. ${ }^{5}$ Buenavista continues to have the largest population ${ }^{6}$ (see Figure 1).

In 2003, the Associación de Cabildos Indígenas del Pueblo Siona (ACIPS), with headquarters in Mocoa, was founded by young Siona who had collaborated with the construction of the Plan de Vida (Portela Guarín et al. 2003). ${ }^{7}$ Its primary goals include the promotion of culture, values and traditional norms and representation of the member cabildos. Over the years it has developed community projects and has attempted to lead negotiations with governmental and non-governmental organizations as well as with industries seeking to extract petroleum in their territories. Its survival depends primarily on national and international support for its projects, which aim to strengthen traditional agriculture practices, food habits, family and community organization, indigenous

5. Some 28 families live in Mocoa and another 45 in Puerto Asís (ACIPS 2012a, p. 40). They have not lost ties with their home territories, and there is constant movement between the indigenous rural communities and urban areas (Musalem Nazar 2015).

6. The census conducted by ACIPS reports a population of 2,578 (ACIPS 2012a, p. 40). This growth is a result of increased intermarriage with mestizos and the "re-ethnicization" process that has resulted from the heightened status afforded to indigenous peoples in Colombia (Chaves Chamorro 2002, 2003).

7. The Plan de Vida (Plan of Life) is a planning strategy for indigenous communities that is constructed through a participative process of self-diagnosis and construction of projects. The fiscal and organizational framework for the development of a Plan de Vida for each indigenous group was inspired by the Organización Nacional de Indígenas de Colombia (ONIC) and its role in the formulation of the 1991 Constitution. 
leadership and ethnoeducation (ACIPS 2014). However, it continues to be hampered by a lack of adequate resources, and its power and influence over the member cabildos are limited primarily to the projects for which it receives funding. As in the colonial past, Siona communities do not represent a single collectivity and conflicts and differences of interests are common within and between communities (Mongua Calderón and Langdon 2020).

The limits of ACIPS's leadership role are exemplified by the free, prior and informed consent process conducted with the Amerisur Petroleum Company. Amerisur sought permission for oil exploration in two Siona resguardos, Buenavista and Piñuña Blanco, in 2012 (Musalem Nazar 2016). ACIPS argued that, as a collective pan-Siona organization, it should represent the Siona in the negotiations. However, both communities refused to grant ACIPS the right to represent them, and each negotiated individually. While Piñuna Blanco consented to petroleum exploration in exchange for certain payments and benefits, Buenavista rejected the company's request in December 2014, in defense of territorial and spiritual preservation. Following this decision, Amerisur continued to pressure Buenavista (Correa 2017), threatening to proceed with exploration, and obtained support from ACIPS's President to persuade Buenavista's leaders into signing an agreement. Although there has been tremendous pressure to submit to Amerisur's demands, the leadership of Buenavista continues to manifest its opposition through community assemblies and complaints filed with governmental authorities. Their legal battles have been enhanced by partnership with Amazon Frontlines, a small non-governmental organization founded to defend indigenous peoples and their territories in Ecuador and Colombia. ${ }^{8}$

\section{Revitalization of shamanism and local political process}

The revitalization of "traditional authorities" and shamanic practices is a remarkable testimony to the Siona's desire to maintain their cultural identity and way of life (Langdon 2016). Two decades after the death of the last cacique curaca in Buenavista, Francisco (Pacho) Piaguaje began to lead yajé ceremonies in the community, and he was soon joined by several other elders as well as his sons. The revitalized shamanic activities were strengthened in part by the interest in tomas de yajé in Colombian cities that began in the 1980s. Amazonian shamans, identified as taitas, became valued for their great wisdom and knowledge and were recruited to lead yajé rituals organized by psychologists or others in the urban areas (Caicedo Fernández 2015). By the early 1990s, several Siona

8. Amazon Frontlines began to aid Buenavista in its legal battles in 2015. Besides legal defense activities, it collaborates with Alianza Ceibo, an indigenous organization that trains youth for cultural revitalization and territorial defense (www.amazonfrontlines.org; www.alianzaceibo.org). 
elders began to respond to this opportunity, partaking in a regional network of shamans and establishing alliances in major cities such as Bogotá, Cali, Medellín and Pasto. In the late 1990s, the Unión de Médicos Indígenas Yageceros de Colombia (UMIYAC) was founded in a meeting organized by the Amazonian Conservation Team and a Quichua indigenous organization (UMIYAC 1999). Several Siona taitas participated in this multi-ethnic gathering, and since then they have conducted yajé rituals throughout Colombia, Latin America, North America and Europe.

The growing external demand for Amazonian taitas accompanied the legal recognition of indigenous political rights and traditional leaders. Siona taitas became identified as traditional leaders within their communities, drawing upon the role of the curacas evident until the 1960s. Their role in the cultural revitalization process is clear in the first Plan de Vida, which outlines seven "pillars of community well-being"-traditional medicine, native language, subsistence, territory, environment, collective control and thought (pensamiento) (Portela Guarín et al. 2003) — and is reaffirmed in subsequent documents (ACIPS 2012a). Taitas are recognized not only as traditional "medicos" but also as traditional authorities responsible for the group's well-being, as protectors and counselors of the communities. Their practices are associated with Siona "thought" (pensamiento, perhaps best translated as ethos or ethics) and environmental and territorial management. ${ }^{9}$

The revitalization of shamanic practices and their role in the political process is most evident in Buenavista, the community with the largest number of contemporary taitas. The governance of the community operates through an alliance of the elected cabildo leaders in consultation with the taitas. They work together for the maintenance of territorial autonomy as well as the continuation of spiritual practices that ensure community, environmental and territorial well-being. Public assemblies are held to discuss important issues such as informed, prior consent; implementation of developmental projects; judicial processes regarding territorial rights, etc. Communal yajé ceremonies precede or follow the assemblies, and the taitas lead the community in deliberating over the issues. After the ceremony, they announce what they have seen in their yajé visions and give advice as to how the community should proceed. When the gobernador makes visits to national or international organizations, a taita usually accompanies him, as a traditional authority of the community. ${ }^{10}$

9. The first ACIPS President (2003-2016) worked in close association with his respected taita father-in-law, who had also migrated to Mocoa from Buenavista. As a traditional authority, he participated in ACIPS's assemblies with the communities and also with governmental and non-governmental representatives, conducting yajé ceremonies after the formal meetings.

10. One of the most interesting efforts at revitalization and defense of territory is the creation of an indigenous guard called "Caretakers of the earth." There is not time to discuss this 
NGOs have recently joined the efforts in Buenavista to revitalize the shamanic practices in Buenavista. Amazon Frontlines, together with its partner Alianza Ceibo, financed the construction of a large ceremonial house (maloca) in 2017 for yajé ceremonies. The Fundación Siona Espiritu ${ }^{11}$, a small philanthropic organization located in Medellín, has established close relations with the taitas in Buenavista and works for the promotion of traditional culture through music and dance. Members of both NGOs are present in rituals in Buenavista, and those of Siona Espíritu wear traditional shamanic dress when they participate.

\section{ACIPS's educational project}

Revitalization of the Siona language has been given priority in both the Plan de Vida (Portela Guarín et al. 2003) and the subsequent Diagnostic Rescue Plan (Diagnóstico Plan Salvaguarda) (ACIPS 2012a), financed by the Ministry of the Interior after the Constitutional Court's pronouncement of the community's endangered physical and cultural survival (2009). Very few people under 60 speak the language, and elders and taitas, who still speak it, are considered repositories of memory and culture. Oral narrations in the Siona language are highly valued as manifestations of their culture and thought. In 2010, ACIPS gained funds from the Ministry of Education to construct a Siona educational model (modelo educativo proprio) for their schools. An outside Educational Coordinator was appointed to design the project from 2010 to 2013, and she visited Siona communities with Felinto and other taitas. Narrative performances by elders were documented on video, and yajé ceremonies were conducted at the end of each visit. ACIPS produced a video documentary in 2012 on the project (ACIPS 2012b), but the many hours of footage of elders' narrative performances in Siona language have not been edited because of a lack of funds. Two older Siona speakers were hired by ACIPS's project and circulated between the Siona communities, attempting to introduce basic notions of the language. In 2014, the first draft of two cycles of the ethnoeducational curriculum to be implemented in Siona schools was completed (ACIPS/Ministerio de Educación Nacional 2013), with a focus on language and territory. However, funding from the Ministry of Education was too limited and too irregular to permit the full development of the project and it ceased in 2013. This provisionary curriculum was neither completed nor implemented.

The development of didactic material remains an unresolved challenge. A few narratives appear in published material (Portela Guarín et al. 2003; ACIPS 2012a; ACIPS/Ministério de Educación Nacional 2013), and some school

initiative, but it is important to mention that the taitas are in charge of teaching the spiritual dimensions of territorial preservation to its members.

11. www.fundacionsionaespiritu.org 
teachers have used them, but there continues to be a lack of culturally specific didactic material. Teachers for schools in the communities are contracted by the municipalities, and although a number of them are Siona, they don't speak the language, including the Coordinator, who communicated to me in 2015 that ACIPS's curriculum proposal is inadequate. In 2018, the Fundación Espiritu Siona began paying a 60 -year-old Siona speaker to teach the language in the Buenavista school. Although without pedagogical training, he has shown strong motivation to help revive the language. His language resources consist primarily of the dictionary and grammar published by Alvaro Wheeler (1987). He did not have any of the mimeographed booklets (cartillas) that Wheeler had distributed during his time among the Siona in the 1970s, nor any material that had been produced by ACIPS's project.

José Francisco (Pacheco) Piaguaje, younger brother of Felinto, is today the most authoritative Siona who can read and write the language. Pacheco completed high-school education and training as a teacher and taught in several schools in the region, including in Buenavista. He worked as a bilingual assistant for Wheeler in the 1980s and has participated in ethnolinguistic training programs. He relocated to Puerto Asís around 2004 and has made several independent efforts to teach the language to the Siona children residing in the multi-ethnic urban community of Nuevo Amanecer. In 2015, he showed me the dictionary and schoolbooks that he has been creating and said that he hopes that his efforts will be financed by some organization. Like the Educational Coordinator in Buenavista, he is at odds with ACIPS.

\section{Digitization and return of ethnographic material}

When I finished my fieldwork in 1973, copies of the audiotapes were deposited with the Instituto Colombiano de Antropologia. ${ }^{12}$ I returned to Buenavista four times to continue to work on the texts, and in 1992 discussed with Felinto the possibility of publishing his narratives. In 1993-1994, I spent a year at Indiana University working with Richard Bauman, and donated the original reel-to-reel audiotapes to the Traditional Music Archives of Indiana University. As a visiting researcher, I revised my transcriptions of the audiotapes and those of Felinto, transferring them onto computer with Microsoft's Word software. Linguistic analysis of some texts was made using the "Shoebox" software developed by the Summer Institute of Linguistics. It was my goal at the time to prepare Felinto's narratives for publication in Colombia under his authorship. Given the mounting violence, I was unable to return for 20 years, but my work with translations continued. Also, I accompanied from afar the transformations in

12. In 2012, I discovered that the copies of my tapes left with the Instituto Colombiano de Antropología had been lost. 
indigenous citizenship in Colombia and the revitalization of Siona shamanism and came to realize that the narrative material in my possession had important potential and value for the Siona's struggles to defend their rights and revitalize their language and shamanism.

It is within this context that I began the return of ethnographic material in digital form. My primary aim has been to familiarize the Siona with the material so that they can use it for their own goals. I conceive of my role as a collaborator in an effort to decolonize ethnographic research. In 2012, ${ }^{13}$ I reestablished contact with Luis Felinto Piaguaje and we spent a week in Popayan working on his texts. Having lost his own handwritten copies of over 40 narratives, he was extremely pleased to know that I had preserved them on computer. It was through Felinto that I first learned of ACIPS's educational project when he told me that he was appointed Agente Comunitario Bilingüe to aid in the search for narratives. We managed to review 10 transcriptions and translations, and he returned to Buenavista with the revised texts in printed form and a USB flash drive that contained his texts. We agreed to continue the work during my next visit; however, when I called him from Bogotá in February of 2013, he said that he couldn't work with me as planned because of obligations with visiting educational consultants. Shortly thereafter he suffered a stroke, affecting his memory seriously and interrupting our work permanently.

In 2013, I visited Mocoa, the capital of the State of Putumayo, and Puerto Asís to visit the Siona living in these cities. In Mocoa, I met with the ACIPS's President and gave him a complete set of digitized photos from the 1970s on USB drives and CDs. ${ }^{14}$ I also returned digital versions of the audiotapes I recorded during my first fieldwork some 40 years earlier. The President of ACIPS received a full set of narratives, and the descendants of the narrators received those told by their relatives organized on CDs. I sat and listened to the recordings with each family group. The sons and daughters of the narrators enjoyed hearing their parents and the narratives; however, the recordings were of little interest to the youth since they couldn't understand them. Later that year, through the aid of a doctoral student, Pedro C. Musalem Nazar (2016), USB flash drives containing the narratives and battery-operated USB players were

13. In 2012-2013, I had the audiotapes digitized while I spent a year of research at the University of Massachusetts.

14. The President subsequently organized the photos in a slide show and exhibited them in assemblies held in the Siona communities on the Putumayo River. I also made paper copies of photos and distributed them to the respective families. Over the years, the Siona have continued to ask for copies and many photos have been reproduced in publications (ACIPS/Ministerio de Educación Nacional 2013), videos (Villota 2016) and websites, including that of the Fundación Siona Espíritu (https://www.fundacionsionaespiritu.org/ preservacioacuten-territorial.html, accessed 01/12/2020). 
distributed to several bilingual elders in Mocoa, Puerto Asís and Buenavista to facilitate listening to the narratives.

In 2014, with the assistance of Musalem Nazar and support of the ACIPS Director of Education, we organized a language workshop in Mocoa. We invited the Siona teachers in the villages on the Putumayo River and ACIPS's former educational consultant, paying for travel expenses. The workshop attracted other Siona living in Mocoa and there were over 30 participants. Luis Felinto was among the four renowned taitas present and the most honored, but due to his health, he did not participate actively. His brother Pacheco served as the leader of the textual revisions that were projected on a screen. For the two days of the workshop, we reviewed six of Felinto's narratives, reading each one line-by-line in order to correct the orthography and translate into Spanish. The participants were animated and dedicated, and raised several issues central to transcription and transmission of language: how to deal with different dialects in the orthography; the cultural relevance of the texts; their potential as didactic material and other possibilities. The younger teachers emphasized the importance of having Siona texts for their students; the participation of elders; and the need for financial support for their transportation costs to different villages as well as for purchasing video and recording equipment, so that the teachers could do their own research with them. At the end of the workshop, they received printed copies of the revised texts as well as digital copies of all of Felinto's narratives on USB drives. I also gave them my recently published book (Langdon 2014). The workshop was filmed for the purpose of producing a video (Langdon and Langdon 2015). ${ }^{15}$

The following year, I returned to Mocoa and Puerto Asís to distribute the video and a small primer containing the narratives revised in the workshop (Langdon and Langdon 2015). Hugo Portela Guarín of the University of Cauca accompanied me, and we watched the video in small family groups in Mocoa and Puerto Asís. We also met with the Educational Director of ACIPS and the Siona Educational Coordinator to view the film, to give them the primer for distribution and to express our desire for further collaboration. It was on this occasion that the Educational Coordinator expressed his dissatisfaction with the curriculum initiated by ACIPS and the continuing need for the development of didactic material. Our meeting was cut short due to their busy agenda, and attempts to offer further collaboration with the Educational Coordinator (via e-mail and visits in 2016 and 2017) were met with no response.

15. Shortly thereafter, Pacheco, with the support of Pedro C. Musalem Nasar and Lucas Villota, received a small grant to conduct language classes in his community in Puerto Asís. We hoped that he would see the potential of the narratives, but he concentrated on teaching the vocabulary from the dictionary he was compiling. 


\section{Collaboration efforts and misunderstandings}

When I was finally able to examine Casas Manrique's manuscripts in 2017 in Bogotá, I was very surprised and elated to find that included among the linguistic notations and research were 70 different short narratives told by Felinto. Excited with the discovery, I contacted the newly elected President of ACIPS, who indicated that the information should be communicated to the council of taitas in a meeting for all Siona to be held in Buenavista in October 2017. Accordingly, I travelled with Camilo Mongua Calderón and my son to Buenavista, arriving on the first day of the ceremony. As instructed by the ACIPS President, we stayed with the organization's Vice-President, also a taita and Felinto's younger brother. We explained the circumstances of finding the manuscripts, their location and gave him the xerox and digital copies in PDF format.

The ceremony was being held to inaugurate an interethnic ceremonial house (maloca) that had been financed by Amazon Frontlines. It was a large event in which indigenous and non-indigenous participants gathered to drink yajé for two nights, officiated by the Siona taitas as well as Secoya, Kofan and Inga shamans. Approximately 100 people participated on the first night and the number doubled on the second night, with people coming from various parts of Colombia and Ecuador. After the yajé ceremony in the new maloca, an assembly or conversatorio was held to celebrate the visiting taitas. We were introduced at the end of the meeting, and I explained how the manuscripts had been discovered and the circumstances of their whereabouts. Camilo spoke of their value and delicate state of preservation. One taita said that I should do another workshop. Felinto, who was present on the first night, remained silent. Some demanded that the manuscripts be kept in an adequate environment with restricted access, and the Siona Educational Coordinator questioned my motives and right to take photos of the manuscripts. The gobernador leading the assembly sensed the building tension and drew the session to a close, indicating that the discussion would be continued after the yajé ceremony the following night.

However, the assembly held the morning after the second night was dedicated to speeches by visiting shamans and by the NGO officials who had financed the construction of the ceremonial house. The President of ACIPS, who recommended that I present information about the manuscripts at this event, did not approach me during two days, nor did he speak in the assembly. Once the ceremony was over, I attempted to meet with Felinto's two brothers, our host in Buenavista and Pacheco. Pacheco briefly talked with me, indicating that there needed to be further deliberations and that they wanted "moderate" help from me, without clarifying further. We left, somewhat frustrated with the lack of communication and of a decisive response as to our collaboration.

It was upon my return to Buenavista in 2018 in association with Amazon Frontlines that I came to understand that the mixed reception the previous year 
reflected a crisis between ACIPS and Buenavista due to the conflict mentioned earlier over Amerisur's request to explore petroleum on the reserve. Besides the fact that ACIPS lacked support in Buenavista, its recommendation to announce the discovery of the manuscripts during the inauguration of the maloca was very poor timing. ACIPS had no role in this event that was celebrating Buenavista's important alliance with Amazon Frontlines and Alianza Ceibo.

\section{Participative collaboration}

Much of Amazon Frontlines' collaboration has been related to legal processes, aiding the Siona of Buenavista to bring demands before the judicial systems of Colombia and Ecuador as well as before the Interamerican Court. Through a partnership with Alianza Ceibo, they work according to a participatory methodology, giving priority to indigenous leadership and decision-making processes. In 2018, one of their lawyers contacted me about my publications and we met via an internet conference in order to discuss mutual interests, including my project to return the ethnographic material. The lawyer volunteered to accompany me on my return trip planned for later that year. My reception by the residents of Buenavista was totally different than the previous year. They welcomed my return warmly, the older generation remembering my years with them in the 1970s. I made visits to all of the taitas' homes, showing them the yajé designs from the 1970s (Langdon 2000), and we listened to the recorded narratives of their elders. A yajé ceremony was specifically held to deliberate over the use of the digitized material, and after the ritual, the taitas and gobernador gathered with me to discuss how to proceed. They decided that the examples of shamanic art should be under the guardianship of the taitas, while the audio narratives would be pertinent to the school. They also requested that I return again in order to present the full extent of the material.

I subsequently returned in 2019, conducting interviews for Amazon Frontlines regarding the impact of the decades of violence as well as familiarizing them with the narrative recordings. I was accompanied by the bilingual school teacher and a young woman leader with pedagogical training. This led to the request for an ethnolinguistic workshop in Buenavista, which was held in January 2020 with elders, school teachers and interested community members. I distributed copies of the primer that accompanied the video of the 2014 workshop in Mocoa (Langdon and Langdon 2015). Camilo Mongua Calderón was present and on the first day we charted the geographical locations of Siona settlements according to their ethnohistorical narratives as well as information from the Capuchin archives (Mongua Calderón and Langdon 2020). For the next three days, we worked on Felinto's texts that related events in Siona settlements during the rubber boom, using the same methodology we had applied in Mocoa. The school teachers requested that I return for another workshop and bring more 
didactic material. That was set for March 2020, but the COVID-19 pandemic interrupted all plans for return.

\section{Decolonizing knowledge and virtual documents}

My ongoing efforts to return digitized ethnographic material have attempted to familiarize the Siona with the nature of its contents so that they can appropriate it for use in their cultural revitalization initiatives. As can be seen from my experience over the last seven years, the use and appropriation of the material depends not only upon its availability in digital form, but also upon political and social contexts and intercommunity relations. My attempts to establish collaboration with the three communities of Puerto Asís, Mocoa and Buenavista demonstrate that as the Siona migrate and regroup, motivated in great part by the violence in their traditional territories, they continue to follow a pattern evident since the Conquest. Communities consist of families allied with a shaman leader, and relations between the communities are characterized by reciprocity and antagonism. Evidence from the narratives indicates that in the past they celebrated feast days together, drinking chicha and dancing. Intermarriage between villages and ethnic groups was common. Shamans travelled to other villages to exchange visions (pinta) and increase their knowledge. Visits always had the potential for jealousy and conflict, and village exchange was accompanied by rivalries and differences evident in the propensity for gossip and witchcraft accusations (Mongua Calderón and Langdon 2020). Because of this tradition, ACIPS is limited in its potential as a pan-Siona organization that coordinates language and cultural revitalization efforts. Although the communities share the principles expressed in the Plan de Vida and Diagnóstico Plan Salvaguarda, each follows individual strategies devised by its leaders. Buenavista, with the largest number of taitas and decades of struggle against invading armed forces, is the most organized with respect to the revitalization of communal yajé rituals and the taitas' role as traditional authority.

Because of Amazon Frontlines' decolonizing methodology and their support of my work, Buenavista has responded collectively with more interest in the potential of the digital material and my collaboration. The taitas have begun to incorporate the yajé motifs from the 1970s in the paintings that decorate the walls of the communal ceremonial house. More importantly, we are organizing workshops in Buenavista at the request of the school teachers. Two teachers have expressed interest in ethnolinguistics, and they are potential candidates for studying the manuscripts of Casas Manrique, once an adequate repository can be found and the manuscripts can be professionally scanned.

It also appears as though the Siona of Buenavista are beginning to understand the potential of the narrative material for their cultural politics. Recently, 
I received a call from the leaders requesting that I explain the meaning of their key term for well-being (huaje) and its relation with the term for "Mother Earth," a concept that circulates today among Amazonian indigenous organizations as part of their ecological defense (Ulloa 2005; Conklin 2002). They also asked for a version of their "origin myth," a request that highlights the potential and the limits of digital recordings of the oral literature from the 1970s.

As with their written counterpart, the return of oral narratives in digital format represents a process of decontextualization and recontextualization of texts that no longer convey the original intentions of the narrators. Our last workshop in Buenavista using narratives to locate early 20th-century Siona settlements demonstrated that the younger generations do not share the collective memory of the corpus of narratives that circulated when all spoke the native language and gathered for narrative performances of the elders. As noted by both Reeves (1988) and Graham (2005) for other Amazonian groups, Siona narratives are created by actors in dialogue, constructed out of shared references of memory and history. Oral histories are continually told and retold in an ongoing process of social reproduction, and there is not a fixed history. Each narrator expresses a particular perspective that accounts for the relevance of the narrative to ongoing events in the context of the act of speaking, and the members of the community are exposed to different versions and perspectives that circulate in the various contexts of performance. Adequate understanding of one narrative depends upon familiarity with the larger body of texts and with a common history and culture. As Becker (1988) observes, oral texts evoke prior texts through dimensions of the said and unsaid in language. Laura R. Graham (2005, p. 260), identifies the a priori in Xavante narrative as an example of intertextuality in dialogue.

When the leaders of Buenavista asked me to translate their origin myth, I was faced with the dilemma as to the problem of the dialogic and intertextual production of Siona texts. They wanted a fixed unified explication of their origins that could be used in judicial processes to document their claims for ancestral territory. I had many ethnohistorical and mythic texts, but I never recorded a single origin myth. I had recordings of various versions of shared critical events, each one collapsing mythic time with different periods of historical time, and also versions of mythic origins of cultural practices but that are not linked to an origin myth. Narratives cannot be easily arranged according to a scheme of linear chronological time or a unidimensional landscape, and those told in the 1970s were concerned with the interaction of multiple worlds and multiple perspectives and not lineal history.

My first response to the request for the origin myth was to translate a narrative that represents a fragment of the Siona's historical memory on the Putumayo River, and to indicate through footnotes the divergent versions in an attempt to capture the dialogic and intertextual nature of oral tradition. This form, while satisfactory to an academic interested in verbal art and intertextuality, 
was not acceptable to them for use as territorial defense. They responded to my translation with the request that I construct a composite form of an origin myth, uniting the different versions and following recognizable chronological time and space. I united various versions of the past to form a metanarrative that was never told in one performance nor by any one narrator, but that reflected the collective memory of their history and origins as told to me in the 1970s.

\section{Concluding thoughts}

Finding a viable way to collaborate with the Siona's political and social revitalization projects has depended upon ongoing social relations between the different communities and success in finding a common ground for collaboration. While my academic focus on the Siona narratives highlighted the creative and poetical knowledge exercised in oral performance, the Siona's appreciation for the digitized material rests on its value as cultural patrimony in a context of ethnic rights and regional violence. Their use of this material is directed by their perceptions of its contribution to their cultural survival as a collectivity in the 21 st century.

Digitized material has important potential for the Siona's ongoing struggles for cultural survival. I have presented this extended case study for the purpose of examining the issues and complexities implicated in the digitization, and translation, of oral literature. As can be seen from the demand for a single origin myth as a fixed text, digitization represents objectification, fixation and decontextualization of the social life of objects, issues present in the debate about museum artifacts (Brown 2003). The principle that guides my anthropological practice of digitization and return of ethnographic material aims to treat respectfully the objects of cultural patrimony according to the desires of the Siona and their needs before the larger society. The process of recontextualizing and fixing oral texts told in performance according to their current needs represents the loss of the dynamics of oral literature and the communicational and poetic strategies that disappear with the death of a language (Harrison 2007). The digitization of Siona oral literature has allowed access to important cultural patrimony, since it contains invaluable information about daily life, political and social organization, ethnohistory, shamanic practices and cosmology (Langdon 2013, 2014, 2018). However, neither the dynamics of oral literature nor the poetics of oral performance are accessible to the population that does not understand the language. The social life of digitized narratives is determined by the contemporary social contexts and the Siona's struggle for cultural survival in the 21 st century. ${ }^{*}$

\footnotetext{
* Manuscrit reçu en février 2020, accepté pour publication en octobre 2020.
} 
Acknowledgements - I thank the reviewers of the first draft of this article for their useful suggestions.

\section{References cited}

ACiPS (Asociación de los Cabildos Indígenas Pueblo Siona)

2012a ZIO BAIN. Diagnóstico Plan Salvaguarda, ACIPS/Ministerio del Interior, Puerto Asís, Putumayo, https://www.mininterior.gov.co/sites/default/files/ pueblo_siona_-_diagnostico_comunitario.pdf, accessed 01/12/20.

2012b Proyecto etnoeducativo Zio Bain. La Cultura Siona Renace, video, Luis Agusto Mora Bejarano (dir.), Mocoa, Putumayo, 17 min.

2014 Hoja de Vida, unpublished manuscript.

ACIPS/Ministerio de EdUCACIÓN NACIONAL

2013 Modelo educativo propio Zio Bain, Ciclo 1 e 2, Secretaría de Educación Departamental del Putumayo/ACIPS, Mocoa.

ACNUR

2006 Informe preparatorio para la Misión internacional de verificación de la situación de derechos humanos y derecho internacional humanitario en Pueblos Indigenas en Colombia. La situación actual sobre la violencia en Pueblos Indigenas en cuatro regiones en Colombia: El Putumayo - Caldas/Riosucio - La Sierra Nevada De Santa Marta - La Guajira, Sabine Kienzl, Informe preparatorio para la "Misión Internacional de Verificación de la Verdad en Pueblos Indígenas", Bogotá, Colombia, (file available for download on the ACNUR website, https://www.acnur.org/, on 29/12/2015) https://nanopdf. BECKER Alton L. com/download/informe-sabine-otros-pueblos_pdf, accessed 30/12/2020.

1988 "Language in particular: a lecture", in Deborah Tannen (ed.), Linguistics in Context. Connecting Observation and Understanding, Ablex Pub. Corp. (Advances in discourse processes, 29), Norwood (NJ), p. 17-35.

BRIGGS Charles L. and Richard BAUMAN

1992 “Genre, intertextuality and Power," Journal of Linguistic Anthropology, 2 (2), p. 131-172.

BRown Michael F.

2003 Who Owns Native Culture?, Harvard University Press, Cambridge.

CAICEdo Fernández Alhena

2015 La alteridad radical que cura. Neochamanismos yajeceros en Colombia, Universidade de los Andes, Bogotá.

Chaves Chamorro Margarita

2002 "Jerarquías de color y mestizaje en la Amazonia occidental colombiana," Revista colombiana de antropologia, 38, p. 189-216.

2003 "Cabildos multiétnicos e identidades depuradas," in Clara Inés Garcia (ed.), Fronteras territories y metáforas, Hombre Nuevo Editores, Medellin, p. 121-135.

Conklin Beth A.

2002 "Shamans versus pirates in the Amazonian treasure chest," American Anthropologist, 104 (4), p. 1050-1061. 
Language documentation and revitalization among the Siona of the Putumayo

Correa Pablo

2017 "Los guardianes del yagé, acosados por una petrolera oleira," El Espectador, January 6, https://www.elespectador.com/noticias/nacional/los-guardianesdel-yage-acosados-por-una-petrolera/, accessed 01/12/20.

Corte Constitucional

2009 Auto 004 de 26 de enero de 2009, Corte Constitucional, Republica de Colombia, http://www.corteconstitucional.gov.co/relatoria/autos/2009/a004-09.htm, accessed 01/12/20.

GRAHAM Laura R.

2005 "'The one who created the sea': Tellings, meanings and intertextuality in the translation of Xavante narrative," in Kay Sammons and Joel Sherzer (ed.), Translating Native Latin American Verbal Art. Ethnopoetics and Ethnography of Speaking, Smithsonian Institution Press, Washington (DC), p. 252-271.

HARRISON K. David

2007 The Extinction of the World's Languages and the Erosion of Human Knowledge, Oxford University Press, New York.

Hershey Robert, Jennifer McCormack and Gillian Newell

2014 "Mapping intergenerational memories (Part I): proving the contemporary truth of the Indigenous past (January 10, 2014)," Arizona Legal Studies Discussion Paper, 14 (1), https://ssrn.com/abstract=2377486 or http://dx.doi.org/10.2139/ ssrn.2377486, accessed 01/12/20.

Kowall Emma

2013 "Orphan DNA: Indigenous samples, ethnical biovalue and postcolonial science," Social Studies of Science, 43 (4, Special Issue "Indigenous Body Parts and Postcolonial Technoscience"), p. 577-597.

LANGDON Esther Jean

1991 "La Historia de la Conquista de Acuerdo a los Indios Siona del Putumayo," in Roberto Pineda Camacho and Beatrice Alzate Angel (eds.), Los Meandros de la Historia en Amazonia, Ediciones Abya-Yala, Quito, p. 13-41.

2000 “A cultura siona e a experiência alucinogêna," in Lux Vidal (ed.), Grafismo Indigena. Estudos de Antropologia Estética, Editor Nobel/EDUSP, São Paulo, [2a. Edição], p. 67-87.

2013 “'La visita a la casa de los tigres': La contextualización en narrativas sobre experiencias extraordinarias," Revista Colombiana de Antropologia, 49 (1), p. 129-152.

2014 La negociación de lo oculto. Chamanismo, medicina y familia entre los Siona del bajo Putumayo, Editora Universidad del Cauca, Popayán, Colombia.

2016 "The revitalization of Yajé shamanism among the Siona: strategies of survival in historical context," Anthropology of Consciousness, 27 (2), p. 180-203.

2018 "Dialogicalidad, conflicto y memoria en etnohistoria siona," Boletín de Antropología, 33 (55), p. 56-76.

LANGDON Alan Stone and Esther Jean LANGDON

2015 Taller de bain coca com el pueblo Siona del Putumayo, Video documentário, National Institute of Research: Brazil Plural (IBP/UFSC), Florianópolis, 30 min, https://www.youtube.com/watch? $=$ =sZUV4cwMOxo, accessed 01/12/20. 
Mongua Calderón Camilo

2018 "Caucho, frontera, indígenas e história regional: un análisis historiográfico de la época del caucho en el Putumayo-Aguarico," Boletín de Antropologia, 33 (55), p. 15-34.

Mongua Calderón Camilo and Esther Jean Langdon

2020 "La etno-etnohistória de los procesos de ocupación y afirmación territorial de los Tucano occidentales del río Putumayo: narrativas siona y fuentes documentales del periodo extractivista 1860-1930," Horizontes Antropológicos, 26 (58), p. 219-255.

Musalem Nazar Pedro C.

2015 "Circuitos políticos en el Putumayo indígena," paper presented in the XV Congreso de Antropología en Colombia "Regiones, 'Postconflicto' y Futuros Posibles" [June, Santa Marta, Colombia].

2016 Xamanismo, memoria e identidade: transformações e continuidades nos processos politicos dos Siona do Putumayo, Colômbia, unpublished doctoral thesis in anthropology, Universidade Federal de Florianópolis, Brazil.

Portela Guarín Hugo, Tulio Enrique Rojas Curieux, Claudia Liliana Astaíza Cuellar, and Franco Ever Yaiguaje Paiyoguaje

2003 Plan de vida del pueblo Siona Ga'ntëya bain, Editorial Universidad del Cauca, Popayán.

ReEves Mary-Elizabeth

1988 "Cauchu Uras: Lowland Quichua histories of the Amazon rubber boom," in Jonathan Hill (ed.), Rethinking History and Myth, University of Illinois Press, Urbana, p. 19-34.

UlloA Astrid

2005 The Ecological Native. Indigenous Peoples' Movements and EcoGovernmentality in Colombia, Routledge, New York.

UMIYAC (Unión de Medicos Indígenas Yageceros de Colombia)

1999 Encuentro de Taitas en la Amazonía Colombiana, UMIYAC, Santafé de Bogotá, Colombia.

ViLlota Lucas

2016 Taita Juan Yaiguaje - Testimunio, video, 25 min. https://www.youtube.com/ watch?v=2o303aI4MYs, accessed 01/12/20.

WASSERSTROM Robert

2014 "Surviving the rubber boom: Cofán and Siona society in the Colombia-Ecuador borderlands (1875-1955)," Ethnohistory, 61 (3), p. 525-548.

WHEELER Alvaro

1970 Grammar of the Siona Language, Colombia, South America, Ph.D. Thesis in Linguistics, University of California, Berkeley.

1987 Gantëya bain (El pueblo siona del río Putumayo, Colombia), Instituto Lingüístico de Verano, Bogotá, 2 vols. 